\title{
ANALISIS PENGARUH ARUS KAS OPERASI DAN LABA AKUNTANSI TERHADAP RETURN SAHAM PERUSAHAAN PERAIH INVESTMENT AWARD (BEST ISSUERS) DI BURSA EFEK INDONESIA
}

\author{
Ika Neni Kristanti \\ ikanenikristanti@gmail.com
}

\begin{abstract}
Investors in investing always expect high stock returns. Therefore, investors should be able to assess which companies have good performance, so the stock return is also high. The financial statements, particularly those relating to information on changes in operating cash flows and corporate accounting profit, are one of the important information that can be used by investors to assess company performance. This study aims to provide empirical evidence related to the effect of operating cash flow and accounting earnings on stock returns.

The data in this study is secondary data obtained from the company's annual financial statements in Indonesia Capital Market Directory (ICMD) and Indonesia Stock Exchange (IDX). This study was conducted using the company population of the company winning the investment award (best issues) 2017 listed on the Indonesia Stock Exchange in 2015 and 2016.

The result of this research is partially variable of operating cash flow (AKO) have positive and significant effect to stock return, while partially, variable of accountancy profit (LAK) have no effect to stock return and simultaneously variable operating cash flow (AKO) and change of accountancy profit (LAK) jointly have a significant effect on stock returns in the company's winning investment award (best issues) 2017 listed on the Indonesia Stock Exchange in 2015 and 2016.
\end{abstract}

Keywords: Operating Cash Flow, Accounting Profit, and Stock Return

\section{Pendahuluan}

Persaingan dunia usaha dalam perekonomian pasar bebas semakin ketat. Hal ini disebabkan semakin banyaknya perusahaan yang berdiri dan berkembang sesuai dengan bertambahnya jumlah unit usaha ataupun meningkatnya kegiatan ekonomi yang ditandai dengan meningkatnya kebutuhan pasar. Pemerintah telah memberikan berbagai kemudahan untuk dapat meningkatkan kegiatan ekonomi, seperti halnya memberikan bantuan permodalan dan memberikan izin untuk usaha. Modal sangat diperlukan bagi kelangsungan suatu usaha, hal ini juga yang merupakan kendala oleh perusahaan.

Lembaga pasar modal sebagai penyedia modal merupakan pelengkap di sektor keuangan terhadap dua lembaga lainnya yaitu bank dan lembaga pembiayaan yang menyediakan modal. Pasar modal memberikan jasanya yaitu menjembatani hubungan antara pemilik dana (investor) dengan peminjam dana (emiten). Para pemodal meminta instrumen pasar modal untuk keperluan investasi portofolionya sehingga pada akhirnya dapat memaksimumkan penghasilan (Usman dalam Supranto, 2004).

Pasar modal menurut Scott dalam Sukojo (2001) adalah pasar untuk dana jangka panjang dimana saham biasa, saham preferen dan obligasi diperdagangkan. Pasar modal sebagai sarana mobilitas dana yang bersumber dari masyarakat ke berbagai sektor yang membutuhkan, memainkan peranan penting dalam perekonomian.

Instrumen pasar modal terbagi atas dua kelompok besar yaitu instrumen kepemilikan (equity) seperti saham dan instrumen utang (obligasi) seperti obligasi perusahaan, obligasi langganan, obligasi yang dapat dikonversikan menjadi saham dan sebagainya. Menurut Jogiyanto (2000), terdapat dua jenis saham yaitu saham biasa (Common Stock) dan saham preferen (Preferred Stock). Saham preferen mempunyai hak-hak prioritas lebih dari 
saham biasa. Hak-hak prioritas dari saham preferen yaitu hak atas deviden yang tetap dan hak terhadap aktiva jika terjadi likuidasi.

Seiring dengan perkembangan pasar modal, kebutuhan akan informasi yang relevan dalam pengambilan keputusan oleh investor juga semakin meningkat. Kegiatan pasar modal tidak terlepas dari tersedianya berbagai macam informasi tentang emiten. Informasi bagi pelaku di lantai bursa tersebut akan mempengaruhi berbagai macam keputusan yang akan diambil yang berakibat pada perubahan atau fluktuasi baik harga maupun kualitas saham yang diperdagangkan. Dalam menentukan apakah investor akan melakukan transaksi di pasar modal, biasanya ia akan mendasarkan keputusan pada berbagai informasi yang dimilikinya. Informasi yang diperoleh dari kondisi intern perusahaan yang lazim digunakan adalah informasi laporan keuangan. Informasi ini digunakan sebagai dasar bagi investor untuk memprediksi return, resiko, atau ketidakpastian jumlah, waktu, dan faktor lain yang berhubungan dengan aktivitas di pasar modal.

Para pemakai laporan keuangan dapat mengevaluasi kemampuan perusahaan dalam menghasilkan kas lebih baik kalau mereka mendapat informasi yang difokuskan pada posisi keuangan, kinerja serta perubahan posisi keuangan. Salah satu informasi yang tersedia di bursa efek adalah laporan keuangan tahunan perusahaan emiten yang telah di audit.

Informasi yang lengkap, relevan, akurat dan tepat waktu sangat diperlukan oleh investor di pasar modal sebagai dasar analisis untuk mengambil keputusan. Informasi tersebut diperlukan untuk mengetahui kondisi emiten, khususnya kondisi keuangan perusahaan emiten. Di dalam pasar modal yang efisien, hargaharga sekuritas mencerminkan informasi relevan yang tersedia. Suad Husnan dalam Rohman (2005) menyatakan bahwa, "Pasar Modal yang efisien adalah pasar yang harga sekuritas-sekuritasnya telah mencerminkan semua informasi yang relevan".

Ada dua cara untuk melihat efisiensi pasar, Jogiyanto (2000) yaitu efisiensi pasar secara informasi (informationally eficient market) dan secara keputusan (decisionally efficient market). Efisiensi pasar secara informasi didasarkan pada ketersediaan informasi. Ada tiga bentuk/tingkatan untuk menyatakan efisiensi pasar secara informasi menurut Fama (Jogiyanto, 2000) yaitu: (1) Efisiensi pasar bentuk lemah (weak form), (2) Efisiensi pasar bentuk setengah kuat (semistrong form), (3) Efisiensi pasar bentuk kuat (strong form).

Informasi yang tepat dan cepat sangat diharapkan investor sebagai dasar pengambilan keputusan. Apabila kinerja perusahaan membaik maka investor akan bereaksi dengan memburu saham perusahaan hingga menyebabkan harga saham akan naik. Namun sebaliknya, bila kinerja perusahaan memburuk maka investor akan menjual saham sehingga harga saham akan menurun. Investor dapat menggunakan laporan keuangan perusahaan untuk menilai kinerja perusahaan. Laporan keuangan tersebut adalah arus kas terutama dari aktivitas operasi dan laba.

Investor secara detail akan mengamati prospek perusahaan di masa yang akan datang dengan mengamati kinerja perusahaan saat ini dan membuat keputusan menanamkan modal pada perusahaan tersebut sehingga berdampak pada keuntungan yang diperoleh pada masa yang akan datang. Akan tetapi pada kenyataannya, laporan keuangan sebagai informasi keuangan tidak selamanya digunakan sebagai pengambilan keputusan oleh investor sehingga kinerja perusahaan yang bagus yang terdapat dalam laporan arus kas dari aktivitas operasi dan laba tidak diikuti dengan kenaikan harga saham sehingga berdampak pada tingkat pengembalian yang diharapkan oleh investor. 


\section{Rumusan Masalah}

Laporan arus kas dari aktivitas operasi dan laba menyajikan informasi dari sebuah perusahaan secara padat dan jelas serta tepat pada kebutuhan investor. Namun, dari penelitian-penelitian sebelumnya terdapat ketidakkonsistenan dari hasil penelitiannya. Hasil penelitian Wilson (1986), Bernard et.al. (1989), Bahnson et.al. (1996, 9-10), Baridwan (1997), Triyono (1998) dan Pradhono (2004) menemukan terdapat kandungan informasi dalam laporan arus kas khususnya arus kas operasi dan earning. Sementara hasil penelitian Clubb (1995) dalam Rohman (2005) menyatakan bahwa kandungan informasi laporan arus kas memberikan dukungan yang lemah bagi investor. Bahkan penelitian Board dan Day (1989) serta Board, dkk (1989) menyatakan tidak adanya hubungan antara data arus kas dan harga saham. Sehingga menarik untuk ditelusuri kembali bagaimana pengaruh arus kas operasi dan laba akuntansi terhadap return saham pada saat ini terutama pada periode 2006-2008.

Berdasarkan permasalahan tersebut di atas, maka dalam penelitian ini dirumuskan masalah sebagai berikut:

1. Bagaimana pengaruh arus kas operasi terhadap return saham pada perusahaan Peraih Investment Award (Best Issuers) yang terdaftar di Bursa Efek Indonesia (BEI) secara parsial?

2. Bagaimana pengaruh laba akuntansi terhadap return saham pada perusahaan Peraih Investment Award (Best Issuers) yang terdaftar di Bursa Efek Indonesia (BEI) secara parsial?

3. Bagaimana pengaruh arus kas operasi dan laba akuntansi terhadap return saham pada perusahaan Peraih Investment Award (Best Issuers) yang terdaftar di Bursa Efek Indonesia (BEI) secara simultan?

\section{Tujuan Penelitian}

Tujuan dari penelitian ini adalah:

1. Untuk mengetahui pengaruh arus kas operasi terhadap return saham secara parsial di BEI.
2. Untuk mengetahui pengaruh laba bersih terhadap return saham secara parsial di BEI.

Untuk mengetahui pengaruh arus kas operasi dan laba bersih terhadap return saham secara simultan di BEI.

\section{Landasan Teori}

\section{A. Pengertian Pasar Modal}

Husnan (1994: 3) menyatakan bahwa pasar modal adalah pasar untuk berbagai instrumen keuangan (sekuritas) jangka panjang yang bisa diperjual belikan baik dalam bentuk hutang maupun modal sendiri, baik yang diterbitkan oleh pemerintah maupun perusahaan swasta. Pasar modal (capital market) adalah suatu perusahaan abstrak yang mempertemukan dua kelompok yang saling berhadapan tetapi mempunyai kepentingan untuk saling mengisi, yaitu calon pemodal (investor) dan pihak yang membutuhkan dana (emiten), dengan kata lain pasar modal adalah tempat (dalam pengertian abstrak) bertemunya penawaran dan permintaan dana jangka menengah dan jangka panjang (Bambang Riyanto, 1993: 164).

\section{Penelitian Terdahulu}

Penelitian sebelumnya banyak mengkaji masalah arus kas khususnya arus kas operasi dan laba akuntansi. Rayburn (1986) dalam Wahyuni (2002), menguji kandungan informasi data arus kas dari operasi dan laba akrual dengan return saham. Variabel bebas dalam penelitian ini adalah operating cash flow, agregat accrual dan, non current accrual sedangkan variabel tidak terikat adalah return saham. Analisis data yang digunakan adalah analisis regresi. Hasilnya menunjukkan bahwa terdapat kandungan informasi operating cash flow dan agregat accrual, sedangkan non current accrual tidak mempunyai kandungan informasi dalam mengestimasi dalam arus kas mendatang. Pada penelitian Rayburn, variabel bebasnya adalah operating cash flow, agregat accrual dan non current accrual, sedangkan pada penelitian ini hanya terdapat 2 variabel yang diteliti. Variabel 
bebasnya adalah laba dan arus kas operasi.

Penelitian Pradhono dan Yulius (2004) meneliti permasalahan yaitu apakah terdapat pengaruh EVA, residual income, earning, dan arus kas operasi terhadap return saham. Populasi penelitian adalah perusahaan yang terdaftar di BEJ pada tahun 2000-2002, sedangkan sampel yang diambil berjumlah 34 perusahaan manufaktur barang konsumsi. Analisis data yang digunakan adalah analisis regresi sederhana. Variabel terikat adalah return saham, sedangkan variabel bebasnya adalah EVA (X1), Residual Income (X2), Earnings (X3), dan Arus kas Operasi (X4). Hasil penelitian dapat diambil kesimpulan bahwa arus kas operasi dan earning berpengaruh positif terhadap return saham. Sedangkan economic value added (EVA) dan residual income tidak berpengaruh signifikan terhadap return saham dikarenakan kerumitan dalam menghitung EVA dan hasil yang kontradiktif antara residual income yang negatif dengan kondisi perusahaan yang dapat membagi deviden. Dari hasil penelitian tersebut, disimpulkan bahwa arus kas operasi mempunyai pengaruh yang paling signifikan terhadap return saham yang diterima oleh pemegang saham.

Penelitian Ali (1994) dalam Wahyuni (2002), menguji kandungan informasi dari laba, modal kerja dari operasi, dan arus kas terhadap return saham. Variabel bebas dalam penelitian ini adalah dari laba, modal kerja dari operasi, dan arus kas sedangkan variabel terikatnya adalah return saham. Analisis data yang digunakan adalah model regresi linier dan non linier. Hasil penelitiannya menunjukkan bahwa arus kas relatif tidak memiliki kandungan informasi dibanding variabel laba dan modal dari operasi. Sedangkan hasil yang diperoleh dengan menggunakan pendekatan non linier menunjukkan bahwa terdapat hubungan antara laba, modal kerja dari operasi, dan arus kas dengan return saham yang berarti terdapat tambahan kandungan informasi dari masing-masing variabel yaitu laba, modal kerja dari operasi dan arus kas. Pada penelitian Ali, variabel bebasnya ada 3 sedangkan pada penelitian ini hanya terdapat 2 variabel yang diteliti. Variabel bebasnya adalah laba dan arus kas operasi. Metode yang digunakan untuk menganalisis data pun berbeda, Ali menggunakan dua metode yaitu regresi linier dan non linier sedangkan pada penelitian ini metode yang digunakan untuk menganalisis data adalah metode regresi linier berganda.

Penelitian Triyono (1998) dalam Wahyuni (2002), menguji kandungan informasi arus kas dari aktivitas pendanaan, investasi, operasi dan laba akuntansi dengan harga dan return saham. Metode yang digunakan adalah dengan memisahkan komponen arus kas. Pengujian yang dilakukan adalah dengan menggunakan dua model yaitu model levels dan model return. Hasil penelitian Triyono menyatakan bahwa dengan modal levels, total arus kas tidak mempunyai hubungan yang signifikan dengan harga saham, tetapi pemisahan total arus kas ke dalam tiga komponen arus kas mempunyai hubungan yang signifikan dengan harga saham. Sedangkan model return, hipotesis nol mengenai tidak adanya hubungan arus kas total, maupun ketiga komponennya dengan return tidak berhasil ditolak yang berarti bahwa tidak terdapat hubungan yang signifikan antara total arus kas, maupun ketiga komponennya dengan return saham. Perbedaan yang mendasar adalah pada penelitian Triyono menggunakan dua model yaitu model levels dan model return. Sedangkan dalam penelitian ini, hanya digunakan model regresi antara return saham dengan laba dan arus kas operasi.

Pengaruh Arus Kas Operasi Terhadap Return Saham

Aktivitas operasi adalah aktivitas penghasil utama pendapatan perusahaan 
(principal revenue activities) dan aktivitas lain yang bukan merupakan aktivitas investasi dan pendanaan, umumnya berasal dari transaksi dan peristiwa lain yang mempengaruhi penetapan laba atau rugi bersih, dan merupakan indikator yang menentukan apakah dari operasi perusahaan dapat menghasilkan kas yang cukup untuk melunasi pinjaman, memelihara kemampuan operasi perusahaan, membayar deviden dan melakukan investasi baru tanpa mengandalkan pada sumber pendanaan dari luar. Sehingga adanya perubahan arus kas dari kegiatan operasi akan memberikan sinyal positif kepada investor, akibatnya investor akan membeli saham perusahaan tersebut yang pada akhirnya meningkatkan return saham.

Hubungan arus kas operasi dengan return saham dapat dijelaskan melalui hasil studi Rayburn (1986) yang menunjukkan adanya hubungan antara arus kas dari kegiatan operasi dan laba akrual terhadap abnormal return. Penelitian serupa juga dilakukan oleh Bowen et al. (1987), Wilson (1986, 1987), Ali and Pope (1995) yang hasilnya menunjukkan adanya kandungan informasi data arus kas dari aktivitas operasi. Ali (1994) dengan menggunakan pendekatan nonlinier memberikan dukungan pada hipotesis bahwa arus kas operasi mempunyai kandungan informasi di luar laba akuntansi. Demikian halnya penelitian Triyono dan Jogiyanto (2000) yang juga menyimpulkan bahwa pemisahan total arus kas ke dalam tiga komponen arus kas, khususnya arus kas operasi, mempunyai hubungan yang signifikan terhadap harga saham. Makin tinggi arus kas dari aktivitas operasi saja perusahaan dapat menjalankan bisnisnya dengan baik.

\section{Pengaruh Laba Akuntansi Terhadap Return Saham}

Menurut Husnan dan Pudjastuti (1998: 134) perusahaan yang memiliki kemampuan untuk meningkatkan laba, cenderung harga sahamnya juga akan meningkat. Maksudnya jika perusahaan memperoleh laba yang semakin besar, maka secara teoritis perusahaan akan mampu membagikan deviden yang semakin besar dan akan berpengaruh secara positif terhadap return saham.

Ali (1994) dalam Triyono (2000) menguji kandungan informasi dari laba, modal kerja operasi, dan arus kas dengan model regresi linear dan nonlinear. Hasil studinya juga menemukan bahwa ketiga variabel tersebut memiliki hubungan dengan return saham dalam regresi nonlinear.

\section{Kerangka Pemikiran}

Investor pada umumnya selalu bersifat risk averter (menghindari resiko) dan seorang yang rasional. Dengan demikian investor dalam mengambil keputusan investasi (menjual atau membeli saham) akan mendasarkan pada informasi baik yang bersifat fundamental maupun teknikal. Salah satu faktor fundamental yang paling sering digunakan adalah arus kas operasi dan laba akuntansi. Arus kas operasi dan laba akuntansi dapat digunakan untuk mengetahui kekuatan dan kelemahan perusahaan. Arus kas operasi dan laba akuntansi dapat juga dipakai sebagai sinyal peringatan awal terhadap kemunduran kondisi keuangan yaitu dengan membandingkan dengan tahun sebelumnya.

Berdasarkan laporan yang berisi kandungan-kandungan informasi yang penting bagi keputusan investasi seorang investor dimana apabila perusahaan memiliki laba yang cukup tinggi dan arus kas operasi yang memadai maka kondisi perusahaan tersebut secara finansial dapat dikatakan baik sehingga akan direspon baik juga oleh investor. Pengaruh dari masing-masing variabel tersebut terhadap return saham dapat digambarkan dalam model seperti ditunjukkan dalam gambar berikut: 


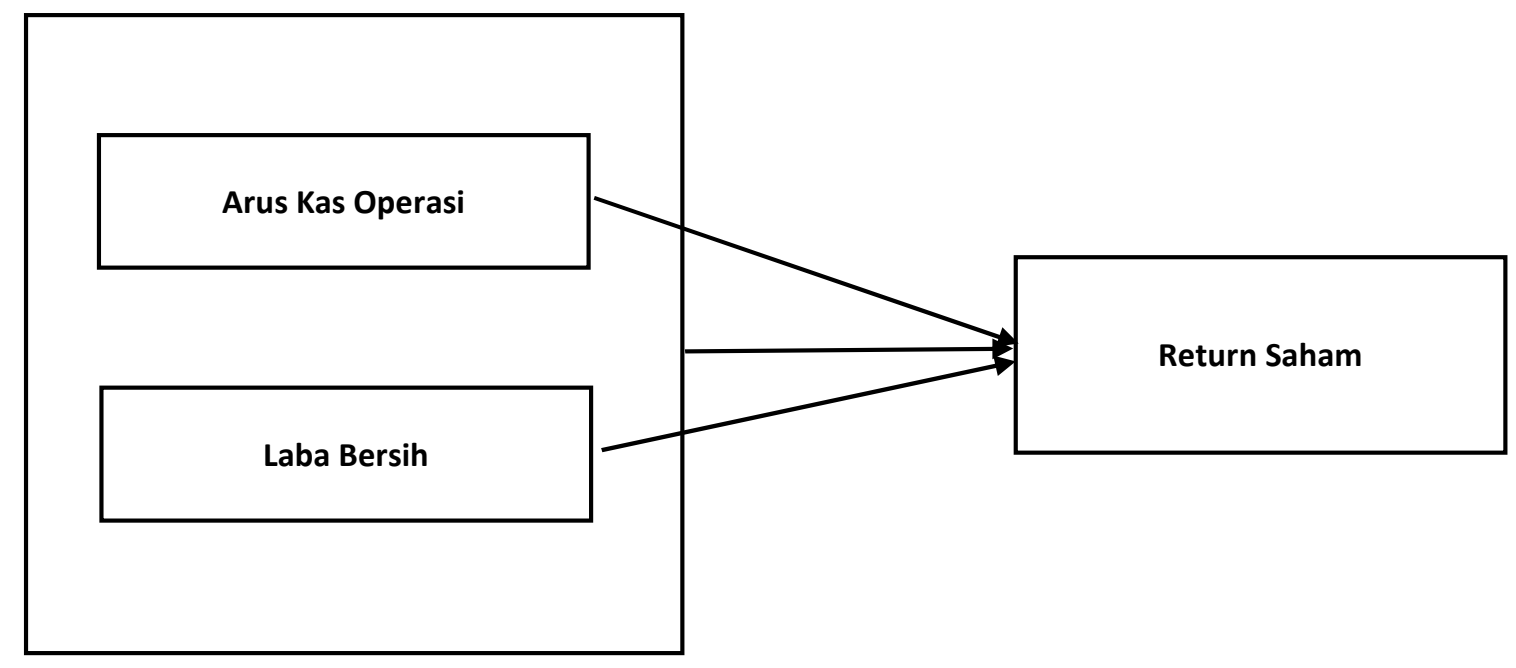

\section{Hipotesis}

Hipotesis merupakan anggapan dasar yang kemudian membuat suatu teori yang masih diuji kebenarannya. Hipotesis akan ditolak jika salah satu palsu dan akan diterima jika fakta-fakta membenarkannya (Suharsimi Arikunto, 1998: 67).

Penolakan atau penerimaan hipotesis tergantung pada hasil penyelidikan terhadap fakta-fakta. Dengan demikian hipotesis adalah suatu teori sementara yang kebenarannya masih diuji. Berdasarkan landasan teori diatas dapat disusun hipotesis penelitian sebagai berikut:

$\mathrm{H}_{1}$ : Arus kas operasi mempunyai pengaruh yang signifikan terhadap return saham secara parsial.

$\mathrm{H}_{2}$ : Laba akuntansi mempunyai pengaruh yang signifikan terhadap return saham secara parsial.
$\mathrm{H}_{3}$ : Arus kas operasi dan laba akuntansi mempunyai pengaruh yang signifikan tehadap return saham secara simultan.

\section{Analisis Pembahasan} Analisis Statistik Deskriptif

Statistik deskriptif digunakan untuk memberikan gambaran atau deskripsi suatu data yang dapat dilihat dari nilai maksimum, nilai minimum dan nilai rata-rata. Dalam penelitian ini variabel yang di gambarkan adalah return saham, arus kas operasi dan laba akuntansi.

1. Return saham merupakan merupakan selisih antara harga saham periode sedang berjalan $(\mathrm{t})$ dengan periode sebelumnya $(\mathrm{t}-$ 1). Berikut ini adalah return saham pada perusahaan peraih investment award (best issues) 2017 yang terdaftar di Bursa Efek Indonesia tahun 2015 dan 2016.

Tabel

Statistik Deskriptif Variabel Return Saham (dalam rupiah)

\begin{tabular}{|c|l|r|}
\hline No & \multicolumn{1}{|c|}{ Nama Perusahaan } & Return saham \\
\hline 1 & PT Provident Agro Tbk & 0,07 \\
\hline 2 & PT Dharma Samudera Fishing Industries Tbk & 0,49 \\
\hline 3 & PT Bumi Teknokultura Unggul Tbk & $-0,32$ \\
\hline 4 & PT Inti Agri Resources Tbk & 0,27 \\
\hline 5 & PT Tunas Baru Lampung Tbk & 0,94 \\
\hline 6 & PT BISI International Tbk & 0,41 \\
\hline 7 & PT Cita Mineral Investindo Tbk & $-0,04$ \\
\hline
\end{tabular}




\begin{tabular}{|c|l|r|}
\hline 8 & PT Elnusa Tbk & 0,26 \\
\hline 9 & PT Radiant Utama Interinsco Tbk & 0,10 \\
\hline 10 & PT Berlina Tbk & 0,51 \\
\hline 11 & PT Mulia Industrindo Tbk & $-0,09$ \\
\hline 12 & PT Indal Aluminium Industry Tbk & 0,59 \\
\hline 13 & PT Panasia Indo Resources Tbk & $-0,34$ \\
\hline 14 & PT Sepatu Bata Tbk & $-0,12$ \\
\hline 15 & PT Nipress Tbk & $-0,17$ \\
\hline 16 & PT Siantar Top Tbk & 0,06 \\
\hline 17 & PT HM Sampoerna Tbk & 0,01 \\
\hline 18 & PT Nippon Indosari Corpindo Tbk & 0,26 \\
\hline 19 & PT Unilever Indonesia Tbk & 0,05 \\
\hline 20 & PT Sekar Laut Tbk & 0,10 \\
\hline 21 & PT Mandom Indonesia Tbk & $-0,24$ \\
\hline & PT Gowa Makassar Tourism Development & $-0,07$ \\
\hline 22 & Tbk & $-0,03$ \\
\hline 23 & PT Adhi Karya Persero Tbk & $-0,88$ \\
\hline 24 & PT Bumi Citra Permai Tbk & 0,81 \\
\hline 25 & PT Cowell Development Tbk & $-1,00$ \\
\hline 26 & PT PP Persero Tbk & 0,53 \\
\hline 27 & PT Waskita Karya Persero Tbk & $-0,10$ \\
\hline 28 & PT Pelayaran Tempuran Emas Tbk & $-0,02$ \\
\hline 29 & PT Steady Safe Tbk & $-0,46$ \\
\hline 30 & PT Tanah Laut Tbk & $-0,14$ \\
\hline 31 & PT Solusi Tunas Pratama Tbk & 0,28 \\
\hline 32 & PT Telekomunikasi Indonesia Persero Tbk & 0,10 \\
\hline 33 & PT Kresna Graha Investama Tbk & 0,20 \\
\hline 34 & PT Batavia Prosperindo Finance Tbk & $-0,43$ \\
\hline 35 & PT Bank of India Indonesia Tbk & $-0,51$ \\
\hline & PT Bank China Construction Bank Indonesia & 0,17 \\
\hline 36 & Tbk & 0,00 \\
\hline 37 & PT Asuransi Ramayana Tbk & $-0,13$ \\
\hline 38 & PT Bank Capital Indonesia Tbk & $-0,14$ \\
\hline 39 & PT Asuransi Bina Dana Arta Tbk & $-0,04$ \\
\hline 40 & PT Matahari Department Store Tbk & 0,00 \\
\hline 41 & PT Indoritel Makmur Internasional Tbk \\
\hline 42 & PT Metrodata Electronics Tbk & 0,28 \\
\hline 43 & PT Bayu Buana Tbk & \\
\hline & Rata-rata & \\
\hline
\end{tabular}

Sumber: Data diolah, 2018

Berdasarkan pengamatan tabel Sedangkan perusahaan yang menghasilkan tersebut diatas diketahui bahwa return terendah pada tahun 2017 adalah PT perusahaan yang memiliki nilai return PP Persero Tbk sebesar -1.00. Sedangkan tertinggi pada tahun 2017 adalah PT nilai rata-rata return saham pada tahun Tunas Baru Lampung Tbk sebesar 0.94. 2016 sebesar 0.02. 
2. Arus kas operasi merupakan arus kas yang digunakan untuk mendanai kegiatan operasional perusahaan pada suatu periode tertentu. Berikut ini adalah return saham pada perusahaan peraih investment award (best issues) 2017 yang terdaftar di Bursa Efek Indonesia tahun 2015 dan 2016.

\section{Uji Asumsi Klasik}

Uji asumsi klasik dimaksudkan untuk mengetahui apakah model regresi dapat dipakai. Uji tersebut meliputi uji normalitas. uji multikoLinearitas. uji autokorelasi. uji heteroskedastisitas dan uji Linearitas.

\section{Uji Normalitas}

Pengujian ini bertujuan untuk mengetahui apakah dalam sebuah model regresi variabel bebas, variabel terikat atau keduanya mempunyai distribusi normal atau tidak. Model regresi yang baik adalah yang memiliki distribusi data normal atau mendekati normal. Adapun analisis menggunakan uji kolmogorov diperoleh hasil sebagai berikut:

Tabel IV-4

Hasil Uji Normalitas

\begin{tabular}{|c|c|c|}
\hline & & $\begin{array}{l}\text { Unstandardiz } \\
\text { ed Residual }\end{array}$ \\
\hline $\begin{array}{l}\text { No } \\
\text { Normal Parameters }{ }^{a, b} \\
\text { Most Extreme } \\
\text { Differences } \\
\text { Test Statistic } \\
\text { Asymp. Sig. (2-tailed) }\end{array}$ & $\begin{array}{l}\text { Mean } \\
\text { Std. } \\
\text { Deviation } \\
\text { Absolute } \\
\text { Positive } \\
\text { Negative }\end{array}$ & $\begin{array}{r}43 \\
.0000000 \\
.33477716 \\
.083 \\
.074 \\
-.083 \\
.083 \\
.200^{\mathrm{c}} \mathrm{d} \\
\end{array}$ \\
\hline $\begin{array}{l}\text { a. Test distribution is } \\
\text { b. Calculated from data } \\
\text { c. Lilliefors Significan }\end{array}$ & mal. & \\
\hline
\end{tabular}

Sumber: Data diolah. 2018

Berdasarkan Tabel IV-4 di atas (One sample Kolmogorov-Smirnov Test) memiliki nilai signifikansi sebesar 0,200 > 0,05 . Hal itu berarti nilai residual terstandarisasi, sehingga dapat disimpulkan bahwa model regresi tersebut memenuhi asumsi normalitas.

\section{Uji MultikoLinearitas}

Uji multikoLinearitas bertujuan untuk mengetahui apakah antara variabel bebas yang satu dengan yang lain di dalam model regresi memiliki hubungan yang sempurna atau mendekati sempurna (koefisien korelasinya tinggi atau bahkan mendekati 1). Bila antar variabel bebas terdapat korelasi sempurna atau mendekati sempurna. maka model analisis regresi tidak dapat digunakan untuk menentukan tinggi rendahnya korelasi antar variabel bebas tersebut. Menurut Ghozali (2016: 103) dasar pengambilan keputusan mengenai ada tidaknya masalah multikoLinearitas dapat dilihat dari nilai tolerance dan VIF (variance inflation factor). Jika nilai tolerance yang rendah sama dengan nilai VIF tinggi. maka menunjukkan adanya kolonieritas yang tinggi (karena $\mathrm{VIF}=1 /$ Tolerance). Nilai Cutoff yang umum dipakai untuk menunjukan adanya multikolinearitas adalah nilai tolerance $<0.10$ atau sama dengan nilai $\mathrm{VIF}>10$. 
Tabel IV-5

Hasil Uji MultikoLinearitas

\begin{tabular}{|l|r|r|}
\hline \multirow{2}{*}{ Model } & \multicolumn{2}{|c|}{ Collinearity Statistics } \\
\cline { 2 - 3 } & \multicolumn{1}{|c|}{ Tolerance } & \multicolumn{1}{c|}{ VIF } \\
\hline $1 \quad$ (Constant) & & \\
AKO & .998 & 1.002 \\
LAK & .998 & 1.002 \\
\hline
\end{tabular}

a. Dependent Variable: Return Saham

Sumber: Data diolah. 2018

Berdasarkan Tabel IV-5 di atas. maka dapat diketahui nilai tolerance untuk variabel Arus Kas Operasi (AKO) dan Perubahan Laba Akuntansi (LAK) masing-masing $>0.1$ dan nilai VIF untuk variabel Arus Kas Operasi (AKO) dan Perubahan Laba Akuntansi (LAK) masing-masing $<10$, sehingga dapat disimpulkan bahwa tidak terdapat multikoLinearitas pada model regresi.

\section{Uji Autokorelasi}

dalam model regresi linear ada korelasi antara kesalahan pengganggu pada periode $\mathrm{t}$ dengan kesalahan pengganggu pada periode $\mathrm{t}-1$ (periode sebelumnya). Jika terjadi korelasi. maka dinamakan ada problem autokorelasi. Autokorelasi keadaan dimana variabel gangguan pada periode sebelumnya. Dalam penelitian ini untuk mendeteksi ada tidaknya autokorelasi maka di gunakan uji DurbinWatson (DW test).

Menurut Ghozali (2016: 107) uji autokorelasi bertujuan menguji apakah

Tabel IV-6

Hasil Uji Autokorelasi

\begin{tabular}{|c|c|c|c|c|c|}
\hline Model & $\mathrm{R}$ & $\begin{array}{c}\mathrm{R} \\
\text { Square }\end{array}$ & $\begin{array}{l}\text { Adjusted } \\
\text { R Square }\end{array}$ & $\begin{array}{c}\text { Std. Error of the } \\
\text { Estimate }\end{array}$ & $\begin{array}{l}\text { Durbin- } \\
\text { Watson }\end{array}$ \\
\hline 1 & $.482^{\mathrm{a}}$ & .233 & .194 & .34304 & 2.153 \\
\hline
\end{tabular}

a. Predictors: (Constant). LAK. AKO

b. Dependent Variable: Return Saham

Sumber: Data diolah. 2018

Berdasarkan Tabel IV-6 dapat diketahui bahwa nilai Durbin Watson (DW) sebesar 2.153. Nilai tersebut berada diantara du $=1.609$ dan $4-\mathrm{du}=2.391$ atau $1.609<2.153<2.391$ dimana daerah tersebut merupakan daerah bebas autokorelasi. Sehingga dapat disimpulkan bahwa dalam penelitian ini model regresi yang digunakan tidak mengandung gejala autokorelasi.

\section{Uji Heteroskedastisitas}

Uji heteroskedastisitas pada penelitian ini menggunakan uji white. Uji ini bertujuan menguji apakah dalam model regresi terjadi ketidaksamaan varians dari residual satu pengamatan ke pengamatan lain. Model regresi yang baik adalah yang homokedastisitas atau tidak terjadi heteroskedastisitas. 
Tabel IV-7

Hasil Uji Heteroskedastisitas

\begin{tabular}{|ll|r|r|}
\hline \multicolumn{1}{|l|}{ Model } & $\mathrm{t}$ & \multicolumn{1}{c|}{ Sig. } \\
\hline 1 & (Constant) & .466 & .644 \\
& AKO & 1.434 & .159 \\
& LAK & -.782 & .439 \\
\hline
\end{tabular}

a. Dependent Variable: ABS_RES

Sumber: Data diolah. 2018

Berdasarkan Tabel IV-7 di atas. maka dapat diketahui bahwa masing-masing variabel memiliki nilai probabilitas atau signifikansi $>0.05$. sehingga dapat disimpulkan bahwa variabel Arus Kas Operasi (AKO) dan Perubahan Laba Akuntansi (LAK) bebas heteroskedastisitas.

\section{Uji Linearitas}

Uji Linearitas digunakan untuk melihat apakah spesifikasi model yang digunakan sudah benar atau tidak.dengan uji linearitas akan diperoleh informasi apakah model empiris sebaiknya linear, kuadrat atu kubik. Dalam penelitian ini uji linearitas dilakukan dengan menggunakan uji Durbin Watson.

Tabel IV-8

Hasil Uji Linearitas

Persamaan 1

Model Summaryb

\begin{tabular}{|l|c|r|r|r|c|}
\hline & & & Adjusted & $\begin{array}{c}\text { Std. Error of the } \\
\text { Estimate }\end{array}$ & $\begin{array}{c}\text { Durbin- } \\
\text { Watson }\end{array}$ \\
\hline 1 & $.482^{\mathrm{a}}$ & .233 & .194 & .34304 & 2.153 \\
\hline
\end{tabular}

a. Predictors: (Constant). LAK. AKO

b. Dependent Variable: Return Saham

Tabel IV-9

Hasil Uji Linearitas

Persamaan 2

Model Summary

\begin{tabular}{|l|c|r|r|r|r|}
\hline $\begin{array}{l}\text { Mode } \\
1\end{array}$ & $\mathrm{R}$ & R Square & $\begin{array}{l}\text { Adjusted } \\
\text { R Square }\end{array}$ & $\begin{array}{c}\text { Std. Error of } \\
\text { the Estimate }\end{array}$ & $\begin{array}{l}\text { Durbin- } \\
\text { Watson }\end{array}$ \\
\hline 1 & $.495^{\mathrm{a}}$ & .245 & .165 & .34924 & 2.203 \\
\hline
\end{tabular}

a. Predictors: (Constant). SQR_X2. AKO. LAK. SQR_X1

b. Dependent Variable: Return Saham

Berdasarkan tabel IV-8 atau hasil persamaan 1 dengan jumlah pengamatan sebanyak 43 dan jumlah variabel independen 2, maka diperoleh nilai dL sebesar 1.4151 dan dU sebesar 1.6091. Nilai tersebut berada diantara $\mathrm{du}=1.609$ dan $4-\mathrm{du}=2.391$ atau $1.609<2.153<$
2.391 dimana daerah tersebut merupakan daerah bebas autokorelasi.

Berdasarkan tabel IV-9 atau hasil persamaan 2 dengan jumlah pengamatan sebanyak 43 dan jumlah variabel independen 4, maka diperoleh nilai $\mathrm{dL}$ sebesar 1.317 dan dU sebesar 1.720. Nilai 
tersebut berada diantara $\mathrm{du}=1.700$ dan 4 $-\mathrm{du}=2.800$ atau $1.700<2.203<2.800$ dimana daerah tersebut merupakan daerah bebas autokorelasi.

\section{Analisis Regresi Linear Berganda}

Analisis Regresi Linier Berganda digunakan untuk mengetahui pengaruh variabel Arus Kas Operasi (AKO) dan Perubahan Laba Akuntansi (LAK) terhadap return saham pada perusahaan peraih investment award (best issues) 2017 yang terdaftar di Bursa Efek Indonesia tahun 2015 dan 2016

Tabel IV-10

Koefisien Regresi Linear Berganda Coefficients $^{\mathrm{a}}$

\begin{tabular}{|c|c|c|c|c|c|}
\hline \multirow[b]{2}{*}{ Model } & \multicolumn{2}{|c|}{$\begin{array}{c}\text { Unstandardized } \\
\text { Coefficients }\end{array}$} & \multirow{2}{*}{$\begin{array}{c}\text { Standardized } \\
\text { Coefficients }\end{array}$} & \multirow[b]{2}{*}{$t$} & \multirow[b]{2}{*}{ Sig. } \\
\hline & $\mathrm{B}$ & Std. Error & & & \\
\hline 1 (Constant) & -1.216 & .411 & & -2.963 & .005 \\
\hline $\mathrm{AKO}$ & .177 & .052 & .472 & 3.404 & .002 \\
\hline LAK & .045 & .074 & .083 & .602 & .551 \\
\hline
\end{tabular}

a. Dependent Variable: Return Saham

Sumber: Data diolah. 2018

Berdasarkan Tabel IV-10 dBpat diketahui bahwa persamaan regresi adalah sebagai berikut;

$$
\mathrm{Y}=-1.216+0.177 \mathrm{X}_{1}+0.045 \mathrm{X}_{2}+
$$
e

$\mathrm{a}=-1.216$ mempunyai arti bahwa apabila tidak terdapat variabel maka return saham (Y) memiliki nilai sebesar -1.216. Dengan kata lain sebelum atau tanpa adanya variabel Arus Kas Operasi (AKO) dan Perubahan Laba Akuntansi memberikan return saham sebesar -1.216.

$\mathrm{b}_{1}=0.177$ mempunyai arti bahwa setiap peningkatan 1 persen arus kas operasi (AKO), maka akan terjadi peningkatan return saham sebesar 0.177 persen.
$=0.045$ mempunyai arti bahwa setiap peningkatan 1 persen perubahan laba akuntansi (LAK), maka akan terjadi peningkatan return saham sebesar 0.045 persen.

\section{Uji Goodness of Fit Model}

Uji t

Uji parsial (Uji t) dalam penelitian ini dimaksudkan untuk mengetahui pengaruh secara parsial variabel arus kas operasi (AKO) dan perubahan laba akuntansi (LAK) terhadap return saham. Ketentuan pengujian. tingkat signifikan sebesar 5\% $(\alpha=0.05)$. tingkat keyakinan sebesar 95\% (0.95).

Tabel IV-11

Tabel Uji t

\begin{tabular}{|l|r|r|r|r|r|}
\hline \multirow{2}{*}{ Model } & \multicolumn{2}{|c|}{$\begin{array}{c}\text { Unstandardized } \\
\text { Coefficients }\end{array}$} & $\begin{array}{c}\text { Standardized } \\
\text { Coefficients }\end{array}$ & \multirow{2}{*}{ t } & \multicolumn{1}{c|}{ Sig. } \\
\cline { 2 - 4 } & \multicolumn{1}{c|}{$\mathrm{B}$} & Std. Error & \multicolumn{1}{c|}{ Beta } & \multicolumn{1}{c|}{$\mathrm{t}$} \\
\hline 1 (Constant) & -1.216 & .411 & & -2.963 & .005 \\
AKO & .177 & .052 & .472 & 3.404 & .002 \\
LAK & .045 & .074 & .083 & .602 & .551 \\
\hline
\end{tabular}

a. Dependent Variable: Return Saham

Sumber: Data diolah. 2018 
Berdasarkan hasil analisis regresi pada Tabel IV-6 diatas maka dapat ketahui bahwa:

1. Dari hasil analisis di atas dapat diketahui bahwa variabel return on equity (ROE) mempunyai nilai thitung $3.404>t_{\text {tabel }} 2.021$ dengan tingkat signifikansi sebesar $0.000<0.05$. maka $\mathrm{H}_{0}$ ditolak dan $\mathrm{H}_{1}$ diterima. Hasil ini menunjukan bahwa arus kas operasi (AKO) berpengaruh positif dan signifikan terhadap return saham.

2. Dari hasil analisis di atas dapat diketahui bahwa variabel dividend payout ratio (DPR) memiliki nilai $\mathrm{t}_{\text {hitung }} 0.602<\mathrm{t}_{\text {tabel }} 2.0221$ dengan tingkat signifikansi sebesar $0.551>$ 0.05. maka $\mathrm{H}_{0}$ diterima dan $\mathrm{H}_{3}$ ditolak. Hasil ini menunjukan bahwa perubahan laba akuntansi (LAK) tidak berpengaruh terhadap return saham.
Uji F

Uji ini digunakan untuk mengetahui apakah semua variabel independen atau variabel bebas yang dimasukan dalam model mempunyai pengaruh secara bersama-sama (simultan) terhadap variabel dependen/terikat. Menurut Ghozali (2016: 96) dasar pengambilan keputusannya adalah sebagai berikut:

a. Jika nilai $F_{\text {hitung }}$ lebih besar dari 4 maka $\mathrm{H}_{0}$ dapat ditolak dan $\mathrm{H}_{\mathrm{a}}$ diterima pada derajat kepercayaan (sig) $<5 \%$.

b. Jika nilai $\mathrm{F}_{\text {hitung }}>\mathrm{F}_{\text {tabel }}$. maka berarti variabel bebasnya secara bersamasama memberikan pengaruh terhadap variabel terikat.

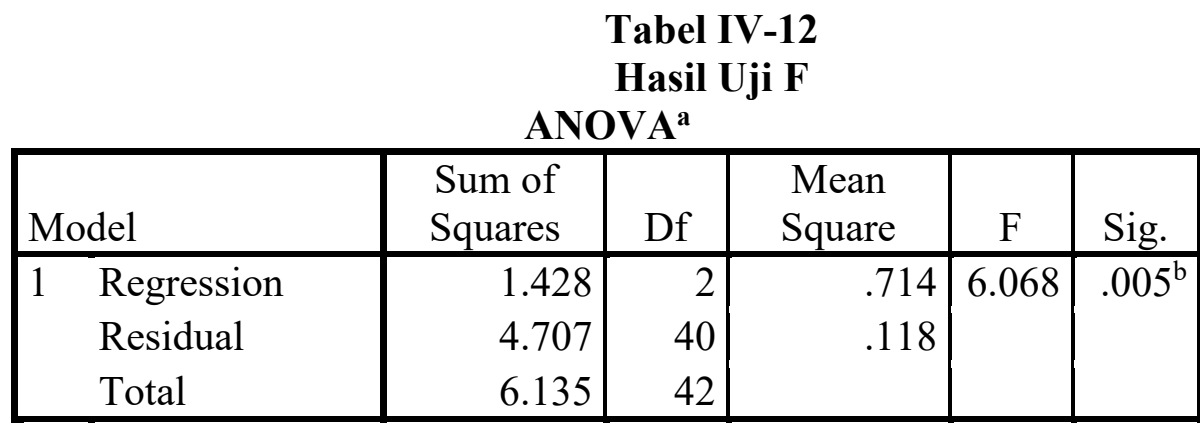

a. Dependent Variable: Return Saham

b. Predictors: (Constant). LAK. AKO

Sumber: Data diolah. 2018

Berdasarkan hasil uji $F$ atau ANOVA pada Tabel IV-12 diperoleh nilai $F_{\text {hitung }}$ sebesar 6.068 lebih besar dari $F_{\text {tabel }}$ sebesar 3. 23 dengan tingkat signifikan $0.005<0.05$. Dengan demikian. maka dapat disimpulkan bahwa secara bersama-sama variabel arus kas operasi (AKO) dan perubahan laba akuntansi (LAK) secara bersamasama berpengaruh signifikan terhadap return saham pada perusahaan perusahaan peraih investment award (best issues) 2017 yang terdaftar di Bursa Efek Indonesia tahun 2015 dan 2016.

\section{Koefisien Determinasi}

Pengujian ini digunakan untuk mengukur besarnya kontribusi variabel independen terhadap variabel dependen. Jika nilai $\mathrm{R}^{2}$ yang diperoleh dari hasil perhitungan semakin besar atau mendekati 1. maka dapat dikatakan bahwa sumbangan dari variabel bebas terhadap variabel terikat semakin besar. Hal ini berarti bahwa model yang digunakan semakin baik untuk menerangkan variasi variabel terikat yang ada. 
Tabel IV-13

Koefisien Determinasi

Model Summary ${ }^{b}$

\begin{tabular}{|l|c|r|r|c|}
\hline Model & $\mathrm{R}$ & R Square & $\begin{array}{c}\text { Adjusted R } \\
\text { Square }\end{array}$ & $\begin{array}{c}\text { Std. Error of the } \\
\text { Estimate }\end{array}$ \\
\hline 1 & $.482^{\mathrm{a}}$ & .233 & .194 & .34304 \\
\hline
\end{tabular}

a. Predictors: (Constant). LAK. AKO

b. Dependent Variable: Return Saham

Sumber: Data diolah. 2018

Berdasarkan Tabel IV-8 di atas nilai adjusted $R^{2}$ sebesar 0.194 artinya kontribusi variabel arus kas operasi (AKO) dan perubahan laba akuntansi (LAK) terhadap return saham adalah sebesar 19,4\%. sedangkan sebesar $80,6 \%(100-19,4)$ dipengaruhi oleh variabel lain di luar model.

\section{Kesimpulan}

Penelitian ini bertujuan untuk meneliti pengaruh antara arus kas operasi dan laba akuntansi terhadap return saham perusahaan perusahaan peraih investment award (best issues) 2017 yang terdaftar di Bursa Efek Indonesia tahun 2015 dan 2016. Berdasarkan hasil penelitian dan pembahasan, maka dapat diambil kesimpulan sebagai berikut:

1. Secara parsial, variabel arus kas operasi (AKO) berpengaruh positif dan signifikan terhadap return saham.

2. Secara parsial, variabel laba akuntansi (LAK) tidak berpengaruh terhadap return saham

3. Secara simultan variabel arus kas operasi (AKO) dan perubahan laba akuntansi (LAK) secara bersamasama berpengaruh signifikan terhadap return saham pada perusahaan perusahaan peraih investment award (best issues) 2017 yang terdaftar di Bursa Efek Indonesia tahun 2015 dan 2016

\section{Saran}

Saran-saran yang dapat penulis kemukakan dalam penelitian ini adalah sebagai berikut:
1. Sebaiknya investor memperhatikan variabel laba akuntansi dalam melakukan investasi saham pada suatu perusahaan, karena semakin besar laba akuntansi berarti semakin tinggi pula return saham perusahaan tersebut, sedangkan arus kas operasi merupakan faktor penting dalam menilai kondisi suatu perusahaan sehingga arus kas operasi juga dijadikan pertimbangan investor dalam berinvestasi, walaupun dalam penelitian tidak terdapat pengaruh yang signifikan arus kas operasi terhadap return saham.

2. Dalam memprediksi return saham, investor perlu memperhatikan faktor lain yang berpengaruh terhadap return saham, misalnya Economic Value Added, Beta, Book Value to Market Equity, EPS, DER, DPR, ROA, ROE, dan ROI maupun kondisi ekonomi, sosial, politik dan keamanan.

3. Dalam penelitian ini lanjutan dengan tema yang sejenis, diharapkan adanya penambahan periode pengamatan dan menambah variabel lain yang belum diteliti, misalnya Economic Value Added, Beta, Book Value to Market Equity dan lainnya.

\section{DAFTAR PUSTAKA}

Algifari. 2000. Analisis Regresi. Yogyakarta : BPFE UGM

Ang, Robert. 1997. Buku Pintar Pasar Modal Indonesia. Jakarta : Media Soft Indonesia 
Al Rasyid, Harum. 1997. Teknik Penarikan Sampel dan Penyusuna Skala. UNPAD: Bandung

Arikunto, Suharsimi. 1997. Prosedur Penelitian dengan Suatu Pendekatan Praktek. Jakarta : Rineka Cipta.

Bambang Riyanto. 1995. Dasar-dasar Pembelajaran Perusahaan. Edisi Keempat. Cetakan Pertama. BPFE. Yogyakarta.

Baridwan, Zaki. 2000. Intermediate Accounting. Yogyakarta : BPFE.

Brigham, Eugene F. Dan Joel F. Houston. 2000. Manajemen Keuangan. Jakarta: Erlangga

Chariri, Anis dan Imam Ghozali. 2000. Teori Akuntansi. Semarang : UNDIP

Dycman, dkk. 2001. Akuntansi Intermediate. Jakarta : Erlangga.
Gultom, Charles Dicknes. 1999. Relevansi Nilai Arus Kas Operasi Terhadap Unexpected Return di Bursa Efek Jakarta. Jurnal Bisnis dan Akuntansi. Vol 1, No. 2.

Jogiyanto. 2000. Teori Portofolio dan Analisis Investasi. Edisi Ketiga. BPFE UGM : Yogyakarta.

Rayburn, Judy. 1986. The Association of Operating Cash Flows and Accruals With Security Return. Journal of Accounting Research: 112-138

Suad Husnan dan Enny Pudjiastuti. 1998. Dasar-dasar Portofolio dan Analisis Sekuritas. Yogyakarta : UPP AMP YKPN.

Tendelilin, Eduardus. 2001. Analisis Investasi Dan Manajemen Portofolio. Edisi Pertama. BPFE. Yogyakarta.

www.idx.co.id 